Org Lett. 2016 August 5; 18(15): 3838-3841. doi:10.1021/acs.orglett.6b01846.

\title{
Rh(III)-Catalyzed C-H Bond Addition/Amine-Mediated Cyclization of Bis-Michael Acceptors
}

\author{
Tyler J. Potter and Jonathan A. Ellman* \\ Department of Chemistry, Yale University, 225 Prospect Street, New Haven, Connecticut \\ 06520-8170, United States
}

\begin{abstract}
A $\mathrm{Rh}$ (III)-catalyzed $\mathrm{C}-\mathrm{H}$ bond addition/primary amine-promoted cyclization of bis-Michael acceptors is reported. The $\mathrm{C}-\mathrm{H}$ bond addition step occurs with high chemoselectivity, and the subsequent intramolecular Michael addition, mediated by a primary amine catalyst, sets three contiguous stereocenters with high diastereoselectivity. A broad range of directing groups and both aromatic and alkenyl $\mathrm{C}-\mathrm{H}$ bonds were shown to be effective in this transformation, affording functionalized piperidines, tetra-hydropyrans, and cyclohexanes.
\end{abstract}

\section{Graphical abstract}

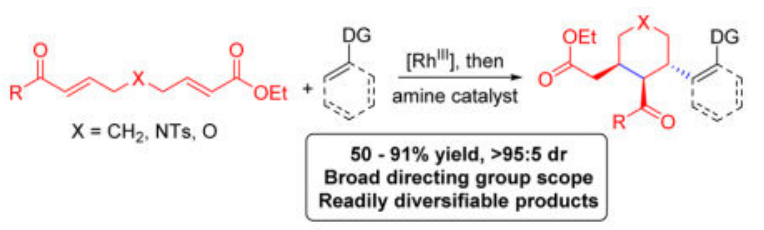

Transition-metal-catalyzed C-H functionalization has emerged as a powerful strategy for the synthesis of important medicinally relevant motifs. ${ }^{1}$ In this regard, pentamethylcyclopentadienyl-ligated rhodium(III) $\left(\mathrm{Cp}^{*} \mathrm{Rh}^{\mathrm{III}}\right)$ catalysts have proven to be very effective for chelation-assisted $\mathrm{C}-\mathrm{H}$ functionalization with high functional group compatibility. ${ }^{2} \mathrm{Rh}$ (III)catalyzed additions to an alkene $\pi$-bond followed by cyclization upon the directing group have in particular been developed as a versatile approach for the rapid generation of various carbo-cyclic and heterocyclic products. ${ }^{3}$

In contrast, to our knowledge, there are only two examples of a $\mathrm{Rh}(\mathrm{III})$-catalyzed $\mathrm{C}-\mathrm{H}$ addition/cyclization sequence involving two tethered electrophiles. Tian, Lin and coworkers reported the synthesis of substituted tetrahydrofurans by $\mathrm{C}-\mathrm{H}$ bond addition to a terminal alkyne followed by cyclization upon a tethered enone (Scheme 1A). ${ }^{4}$ As well, we have recently demonstrated a $\mathrm{Rh}(\mathrm{III})$-catalyzed $\mathrm{C}-\mathrm{H}$ addition/cyclization cascade using substrates

\footnotetext{
*Corresponding Author: jonathan.ellman@yale.edu.

Notes

The authors declare no competing financial interest.

Supporting Information

Experimental details; characterization data; crystallographic data (CIF) for $\mathbf{4 n}$. The Supporting Information is available free of charge on the ACS Publications website.
} 
containing an enone tethered to an aldehyde (Scheme 1B). ${ }^{5,6}$ This reaction produces cyclic $\beta$-hydroxy ketones containing three contiguous stereocenters and proceeds in high yields and with high diastereoselectivity.

Herein, we have expanded the types of tethered electrophiles that can be employed by implementing a sequential catalysis approach with the initial $\mathrm{Rh}(\mathrm{III})$-catalyzed $\mathrm{C}-\mathrm{H}$ bond addition step followed by an organocatalytic transformation as demonstrated for $\mathrm{C}-\mathrm{H}$ addition/primary amine-mediated cyclization of bis-Michael acceptors (Scheme 1C). ${ }^{7}$ Piperidines, tetrahydropyrans, and cyclohexanes with three contiguous stereocenters were synthesized in good to excellent yields and with very high diastereoselectivities for a variety of directing groups and for both aromatic and alkenyl $\mathrm{C}-\mathrm{H}$ bonds.

We began our investigation by employing amine tethered bis-Michael acceptor $\mathbf{1 a}$ and pyridyl C-H functionalization substrate 2a (Table 1). We reasoned that the enone and enoate functionality of 1a would provide sufficient electronic differentiation to enable chemoselectivity in the initial $\mathrm{Rh}$ (III)-catalyzed $\mathrm{C}-\mathrm{H}$ addition step. Using $\left[\mathrm{Cp}^{*} \mathrm{RhCl}_{2}\right]_{2}$ as a precatalyst and $\mathrm{AgSbF}_{6}$ as the chloride abstractor with $20 \mathrm{~mol} \%$ of $\mathrm{AcOH}$ in 1,4-dioxane as solvent, $89 \%$ of the conjugate addition product 3a was observed (entry 1). Although desired product $4 \mathbf{a}$ was not formed, we noted excellent chemoselectivity for the $\mathrm{Rh}(\mathrm{III}) \mathrm{C}-\mathrm{H}$ addition across the alkene of the enone. In the absence of $\left[\mathrm{Cp} * \mathrm{RhCl}_{2}\right]_{2}$ or $\mathrm{AgSbF}_{6}$, no reaction was observed (entries 2 and 3). After significant screening of solvents, temperatures, and additives, $\mathbf{4 a}$ was not observed, leading us to conclude that the Rh-enolate formed upon addition was unreactive towards the tethered enoate. At this point, we hypothesized that an amine catalyst could be used to promote the intramolecular cyclization through an enamine intermediate. ${ }^{8}$ When $20 \mathrm{~mol} \%$ of $\mathrm{BnNH}_{2}$ and water were added to the reaction mixture simultaneously with the other reagents, $43 \%$ of $\mathbf{3 a}$ was observed as well as $22 \%$ of the desired piperidine product $\mathbf{4 a}$ with $>95: 5$ diastereoselectivity (entry 4). Upon increasing the amount of $\mathrm{BnNH}_{2}$ to $100 \mathrm{~mol} \%$ no conversion to 3a or 4a was observed due to inhibition of the $\mathrm{Rh}(\mathrm{III})$-catalyzed $\mathrm{C}-\mathrm{H}$ bond addition step (entry 5). ${ }^{9}$ When $20 \mathrm{~mol} \%$ of $\mathrm{BnNH}_{2}$ and water were added to the reaction mixture after 20 hours, full conversion to $4 \mathbf{a}$ was observed, resulting in a $92 \%$ isolated yield (entry 6). Given the very low cost of $\mathrm{BnNH}_{2}$, the addition of $100 \mathrm{~mol} \%$ was also evaluated, and after 20 hours a similar yield was obtained (entry 7). These conditions ultimately proved to be more general across a broader range of electrophiles and $\mathrm{C}-\mathrm{H}$ functionalization substrates (vide infra). It should be noted that for entries 6 and 7 the crude reaction mixtures contained some of the $N$-benzyl imine of 4a, which readily hydrolyzed to $\mathbf{4 a}$ on silica during purification and thus resulted in higher isolated yields relative to the corresponding NMR yields.

After identifying efficient conditions for the formation of piperidine 4a, we next explored the scope of the bis-Michael acceptor (Scheme 2). The corresponding ethyl enone was an effective coupling partner affording piperidine $\mathbf{4 b}$ in high yield. Tetrahydropyranyl (4c) and cyclohexanyl (4d) products could also be obtained in good yields and with high diastereoselectivities (>95:5) by substituting the nitrogen atom in the tether for an oxygen and carbon atom, respectively. An aryl enone underwent facile $\mathrm{Rh}(\mathrm{III})$-catalyzed $\mathrm{C}-\mathrm{H}$ addition, though enamine cyclization and hydrolysis proceeded much more slowly. By increasing the $\mathrm{BnNH}_{2}$ loading to $200 \mathrm{~mol} \%$ and excluding water, the cyclization product 
was isolated as imine $\mathbf{4 e}$ in good yield. No conversion was observed when the ester was replaced with nitrile functionality $(\mathbf{4 f})$, which is consistent with previously reports that nitriles can coordinate to and deactivate $\mathrm{Rh}(\mathrm{III}) \mathrm{C}-\mathrm{H}$ functionalization catalysts. ${ }^{10}$

We next explored the scope of the $\mathrm{C}-\mathrm{H}$ functionalization coupling partner (Scheme 3). When using 2-phenylpyridine, $\mathbf{4 g}$ could be isolated in pure form and in good yield, although minor byproducts arising from bis-C-H functionalization were observed by LC-MS analysis of the unpurified reaction product. To prevent over addition, the remainder of $\mathrm{C}-\mathrm{H}$ functionalization substrates with nitrogen heterocycle directing groups incorporated metamethyl blocking groups on the aromatic ring to prevent bis-C-H functionalization. The pyrimidine (4h) and pyrazole (4i) $\mathrm{C}-\mathrm{H}$ bond partners were very effective in the transformation while triazole $(\mathbf{4 j})$ provided a more modest yield. Synthetically useful benzamide substrates (4k and $\mathbf{4 l}$ ) were also effective. Electron rich $(\mathbf{4 m})$, electron neutral (4n and 4o), and electron poor (4p) substituents performed well and provided moderate to good yields of the piperidine products.

Each of the products was obtained with $>95: 5$ diastereoselectivity. Moreover, the relative stereochemistry of $\mathbf{4 n}$ was rigorously confirmed by $x$-ray structural analysis.

In addition to aromatic $\mathrm{C}-\mathrm{H}$ bond coupling partners, alkenyl substrate 5 was effective in this transformation, affording 6 in 66\% yield with $>95: 5 \mathrm{dr}$ (eq 1).

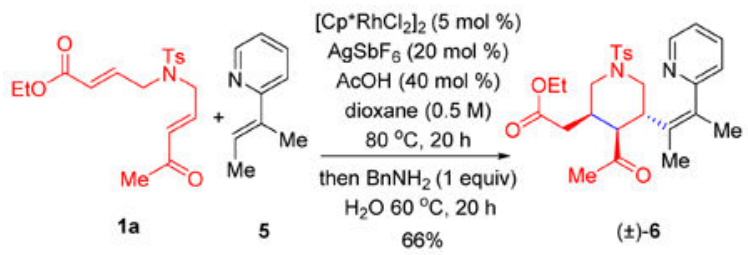

To showcase the utility of this $\mathrm{C}-\mathrm{H}$ functionalization/cyclization sequence, piperidine $\mathbf{6}$ was efficiently transformed to useful, fused bicyclic heterocycle products (Scheme 4).

Ozonolysis of $\mathbf{6}$ in the presence of pyridine yielded the 1,4-dicarbonyl 7 in good yield. ${ }^{11}$ Paal- Knorr furan and pyrrole synthesis then afforded the piperidine-fused furan $\mathbf{8}$ and pyrrole 9 in $80 \%$ and $91 \%$ yield, respectively.

A mechanism for the sequential $\mathrm{Rh}$ (III)-catalyzed $\mathrm{C}-\mathrm{H}$ addition/amine-catalyzed cyclization of bis-Michael acceptors is depicted in Scheme 5. First, concerted metalation/deprotonation of 2 generates rhodacycle $\mathbf{1 0} .{ }^{12}$ Coordination of the enone $\pi$-bond provides 11, which upon insertion into the enone generates rhodium enolate 12, with $\eta^{3}$-coordination depicted consistent with prior $\mathrm{x}$-ray structural characterization of a $\mathrm{Cp} * \mathrm{Rh}(\mathrm{III})$ enolate obtained by enone insertion. ${ }^{5 a}$ Proto-demetalation of $\mathbf{1 2}$ releases the conjugate addition intermediate $\mathbf{3}$ and cyclometallation with 2 regenerates rhodacycle $10 .{ }^{13}$ In the second step, condensation of $\mathrm{BnNH}_{2}$ and $\mathbf{3}$ provides enamine 13. ${ }^{14}$ Intramolecular Michael addition must then proceed with the enoate in the pseudo-axial position as shown in $\mathbf{1 4}$ to provide the observed relative 
stereochemistry of the product as rigorously determined for $\mathbf{4 n}$ by $\mathrm{x}$-ray analysis. This enoate geometry presumably minimizes steric interactions with the R-substituent. Hydrolysis of $\mathbf{1 5}$ then liberates the cyclic product 4.

In conclusion, we have developed a sequential $\mathrm{Rh}$ (III)-catalyzed $\mathrm{C}-\mathrm{H}$ bond addition/primary amine-mediated intramolecular Michael reaction sequence for the efficient preparation of functionalized piperidines, tetrahydropyrans, and cyclohexanes. The $\mathrm{C}-\mathrm{H}$ bond addition step occured with high chemoselectivity, and the subsequent intramolecular enamine-Michael addition set three contiguous stereocenters with high diastereoselectivity. Secondary and tertiary amides as well as various nitrogen heterocycles were effective directing groups. Moreover, alkenyl $\mathrm{C}-\mathrm{H}$ functionalization followed by ozonolysis provided a 1,4-diketone that could readily be converted to piperidine-fused pyrrole and furan products in high yields. Future efforts will focus on further increasing electrophile scope through the implementation of sequential $\mathrm{Rh}$ (III)-catalyzed $\mathrm{C}-\mathrm{H}$ bond addition followed by organocatalytic transformations.

\section{Supplementary Material}

Refer to Web version on PubMed Central for supplementary material.

\section{Acknowledgments}

This work was supported by the NIH (R01-GM069559). We gratefully acknowledge Dr. Brandon Mercado (Yale University) for solving the crystal structure of $\mathbf{4 n}$.

\section{References}

1. For select recent reviews on $\mathrm{C}-\mathrm{H}$ functionalization, see: Yamaguchi J, Yamaguchi AD, Itami K. Angew Chem, Int Ed. 2012; 51:8960.Wencel-Delord J, Glorius F. Nat Chem. 2013; 5:369. [PubMed: 23609086] Yang L, Huang H. Chem Rev. 2015; 115:3468. [PubMed: 25749375] Chen Z, Wang B, Zhang J, Yu W, Liu Z, Zhang Y. Org Chem Front. 2015; 2:1107.

2. For reviews on $\mathrm{Rh}(\mathrm{III})$-catalyzed $\mathrm{C}-\mathrm{H}$ functionalization, see: Satoh T, Miura M. Chem-Eur J. 2010; 16:11212. [PubMed: 20740508] Patureau FW, Wencel-Delord J, Glorius F. Aldrichimica Acta. 2012; 45:31.Song G, Wang F, Li X. Chem Soc Rev. 2012; 41:3651. [PubMed: 22377832]

3. For leading references, see: Ueura K, Satoh T, Miura M. Org Lett. 2007; 9:1407. [PubMed: 17346060] Wang F, Song G, Li X. Org Lett. 2010; 12:5430. [PubMed: 21038874] Guimond N, Gorelsky SI, Fagnou K. J Am Chem Soc. 2011; 133:6449. [PubMed: 21452842] Hyster TK, Knorr L, Ward TR, Rovis T. Science. 2012; 338:500. [PubMed: 23112327] Wang H, Glorius F. Angew Chem Int Ed. 2012; 51:7318.Ye B, Cramer N. Science. 2012; 338:504. [PubMed: 23112328] Zhu C, Falck JR. Tetrahedron. 2012; 68:9192. [PubMed: 23087489] Neely JM, Rovis T. J Am Chem Soc. 2013; 135:66. [PubMed: 23244023] Shi XY, Li CJ. Org Lett. 2013; 15:1476. [PubMed: 23470191] Shi Z, Grohmann C, Glorius F. Angew Chem Int Ed. 2013; 52:5393.Neely JM, Rovis T. J Am Chem Soc. 2014; 136:2735. [PubMed: 24512241] Piou T, Rovis T. J Am Chem Soc. 2014; 136:11292. [PubMed: 25093811] Shi Z, Boultadakis-Arapinis M, Koester DC, Glorius F. Chem Commun. 2014; 50:2650. Wodrich MD, Ye B, Gonthier JF, Corminboeuf C, Cramer N. Chem Eur J. 2014; 20:15409. [PubMed: 25283798] Zhao D, Lied F, Glorius F. Chem Sci. 2014; 5:2869.Hyster TK, Dalton DM, Rovis T. Chem Sci. 2015; 6:254. [PubMed: 25489470] Romanov-Michailidis F, Sedillo KF, Neely JM, Rovis T. J Am Chem Soc. 2015; 137:8892. [PubMed: 26154248] Wu S, Zeng R, Fu C, Yu Y, Zhang X, Ma S. Chem Sci. 2015; 6:2275.Zhao D, Vasquez-Cespedes S, Glorius F. Angew Chem Int Ed. 2015; 54:1657.Wang Q, Li Y, Qi Z, Xie F, Lan Y, Li X. ACS Catal. 2016; 6:1971.Yang W, Wang J, Wei Z, Zhang Q, Xu X. J Org Chem. 2016; 81:1675. [PubMed: 26848995] Weinstein AB, Ellman JA. Org Lett. 2016; 18:3294. [PubMed: 27337641] 
4. Fukui Y, Liu P, Liu Q, He ZT, Wu NY, Tian P, Lin GQ. J Am Chem Soc. 2014; 136:15607. [PubMed: 25338263]

5. Boerth JA, Ellman JA. Chem Sci. 2016; 7:1474. [PubMed: 26918112] For a related Co(III)catalyzed intermolecular C-H bond addition to enones and aldehydes, see: Boerth JA, Hummel JR, Ellman JA. Angew Chem Int Ed. 2016; Early View. doi: 10.1002/anie.201603831

6. For the Rh(III)-catalyzed hydroarylation of enones, see: Yang L, Correia CA, Li CJ. Org Biomol Chem. 2011; 9:7176. [PubMed: 21850341] Yang L, Qian B, Huang H. Chem-Eur J. 2012; $18: 9511$. [PubMed: 22744877]

7. For an impressive example of $\mathrm{Rh} / \mathrm{Pd}$ sequential catalysis, see: Zhang L, Qureshi Z, Sonaglia L, Lautens M. Angew Chem Int Ed. 2014; 53:13850.

8. For cyclization of ketones tethered to enoates with a primary amine via an enamine intermediate, see: Dumas F, d'Angelo J. Tetrahedron: Asymmetry. 1990; 1:167.Hirai Y, Terada T, Yamazaki T, Momose T. J Chem Soc Perkin Trans 1. 1992:509.Zi W, Yu S, Ma D. Chem Asian J. 2011; 6:573. [PubMed: 21254431]

9. Lian Y, Hummel JR, Bergman RG, Ellman JA. J Am Chem Soc. 2013; 135:12548. [PubMed: 23957711]

10. Tsai AS, Tauchert ME, Bergman RG, Ellman JA. J Am Chem Soc. 2011; 133:1248. [PubMed: 21204527]

11. Willand-Charnley R, Fisher TJ, Johnson BM, Dussault PH. Org Lett. 2012; 14:2242. [PubMed: 22512349]

12. For select relevant mechanistic studies for Rh(III)-catalysis, see: Li L, Brennessel WW, Jones WD. J Am Chem Soc. 2008; 130:12414. [PubMed: 18714995] Tauchert ME, Incarvito CD, Rheingold AL, Bergman RG, Ellman JA. J Am Chem Soc. 2012; 134:1482. [PubMed: 22257031] Li Y, Zhang XS, Li H, Wang WH, Chen K, Li BJ, Shi ZJ. Chem Sci. 2012; 3:1634.Walsh AP, Jones WD. Organometallics. 2015; 34:3400.

13. A competition experiment was conducted with an equimolar ratio of deuterio- and protio-2phenylpyridine and 1a under the standard reaction conditions. Consistent with the studies of Huang and coworkers (see ref. 6b), extensive protio-deuterio scrambling of both 2-phenylpyridine and the addition product 3 was observed even at low conversion indicating highly reversible $\mathrm{C}-\mathrm{H}$ activation (see Supporting Information).

14. In the primary amine catalysis literature, both the E- and Z-enamines have been proposed to be operational in various transformations. Either isomer gives the same overall stereochemical outcome. For select reviews on primary amine catalysis, see: Chen YC. Synlett. 2008; 2008:1919.Zhang L, Fu N, Luo S. Acc Chem Res. 2015; 48:986. [PubMed: 25831453] 
A. Previous work by Tian, Lin et al.:<smiles>[R]C1(OCC#C)C=CC(=O)C=C1</smiles><smiles>CONC(=O)c1ccccc1</smiles>

Alkyne Insertion followed by intramolecular Michael addition<smiles>[R][R]C12C=CC(=O)CC1C(=Cc1ccccc1C(=O)NOC)CO2</smiles>

B. Previous work by Ellman et al::<smiles>[X]CCC=CC([R])=O</smiles><smiles></smiles>

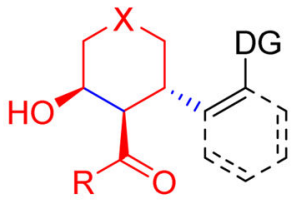

$\mathrm{X}=\mathrm{CH}_{2}, \mathrm{NTs}, \mathrm{O}$

$\left[\mathrm{Rh}^{\prime \prime}\right]$

Cascade $\mathrm{C}-\mathrm{H}$ addition/ intramolecular aldol addition

C. This work:<smiles>[X]CC/C=C/C(=O)OCC</smiles>

$\mathrm{X}=\mathrm{CH}_{2}, \mathrm{NTs}, \mathrm{O}$<smiles>[X]CC1CC(CC(=O)OCC)C(C([R])=O)[C@H]1c1ccccc1[O-]</smiles>
amine catalyst

Sequential C-H addition/ intramolecular Michael addition

Scheme 1.

$\mathrm{Rh}(\mathrm{III})$-catalyzed $\mathrm{C}-\mathrm{H}$ addition/cyclization sequences involving tethered electrophiles 


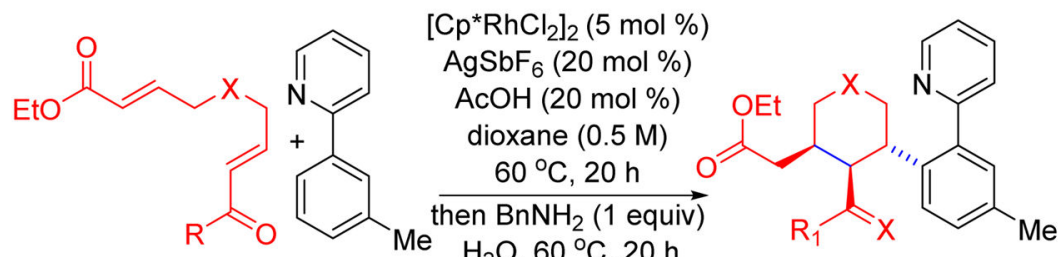

1 (1 equiv) 2a (1.5 equiv)

$( \pm)-4(X=O, N B n)$<smiles>[X]c1ccc([C@H]2CN([3H])C[C@@H](CC(=O)OCC)[C@H]2C(C)=O)c(-c2ccccn2)c1</smiles><smiles>[3H]N1CC(CC(=O)OCC)C(C(=O)CC)[C@@H](c2ccc(C)cc2-c2ccccn2)C1</smiles><smiles>CCOC(=O)CC1COC[C@H](c2ccc(C)cc2-c2ccccn2)C1C(C)=O</smiles>

4a, $90 \%$

4b, $81 \%^{c}$

4c, $68 \%$<smiles>[X]c1ccc(-c2ccccn2)c([C@@H]2CCC[C@@H](CC(=O)OCC)C2C(C)=O)c1</smiles>

4d, $75 \%$<smiles>CCOC(=O)CC1CCC[C@H](c2ccc(C)cc2-c2ccccn2)[C@H]1/C(=N/c1ccccc1)c1ccccc1</smiles>

$4 e, 75 \%^{\circ}$<smiles>[3H]N1C[C@@H](CC#N)C(C(C)=O)[C@@H](c2ccc(C)cc2-c2ccccn2)C1</smiles>

4f, $0 \%$

Scheme 2. Scope for Tethered Electrophile ${ }^{a, b}$

${ }^{a}$ Conditions: $0.20 \mathrm{mmol}$ of $\mathbf{1}$ and $0.3 \mathrm{mmol}$ of $\mathbf{2 a}$ in dioxane $(0.5 \mathrm{M}) .{ }^{b}$ Isolated yields after silica gel chromatography. ${ }^{c}$ Reaction conducted using $40 \mathrm{~mol} \%$ of $\mathrm{AcOH}$ and $40 \mu \mathrm{L}$ of $\mathrm{H}_{2} \mathrm{O}$ instead of $20 \mu \mathrm{L}$ of $\mathrm{H}_{2} \mathrm{O}$. ${ }^{d}$ Reaction conducted using $200 \mathrm{~mol} \%$ of $\mathrm{BnNH}_{2}$ and no water. 
<smiles></smiles>

$\left[\mathrm{Cp}^{*} \mathrm{RhCl}_{2}\right]_{2}(5 \mathrm{~mol} \%)$

$\mathrm{AgSbF}_{6}(20 \mathrm{~mol} \%)$

$\mathrm{AcOH}(20 \mathrm{~mol} \%)$

dioxane $(0.5 \mathrm{M})$

$\frac{60{ }^{\circ} \mathrm{C}, 20 \mathrm{~h}}{\text { then } \mathrm{BnNH}_{2}(1 \text { equiv) }}$

$\mathrm{H}_{2} \mathrm{O}, 60^{\circ} \mathrm{C}, 20 \mathrm{~h}$

1a (1 equiv) 2 (1.5 equiv)

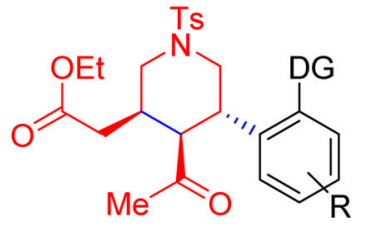

$( \pm)-4$<smiles>CCOC(=O)CC1C[NH2+][CH]C(c2ccccc2-c2ccccn2)C1C(C)=O</smiles><smiles></smiles><smiles>CCOC(=O)CC1C[NH2+]C[C@H](c2ccc(C)cc2-n2cccn2)C1C(C)=O</smiles><smiles>[Y]c1ccc([C@H]2CN([3H])C[C@@H](CC(=O)OCC)[C@H]2C(C)=O)c(-c2cn(Cc3ccccc3)nn2)c1</smiles>

4h, $87 \%$

4i, $91 \%$

4 j, $50 \%$<smiles>CCOC(=O)CC1C[NH2+]C[C@H](c2ccccc2C(=O)N2CCCC2)[C@H]1C(C)=O</smiles>

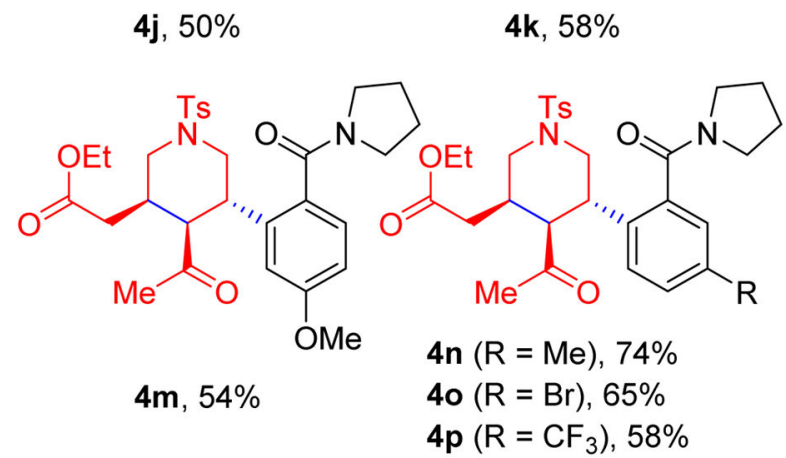

$4 \mathrm{I}, 65 \%$

Scheme 3. C-H Functionalization Substrate Scope ${ }^{a, b}$

${ }^{a}$ Conditions: $0.20 \mathrm{mmol}$ of $\mathbf{1}$ and $0.3 \mathrm{mmol}$ of $\mathbf{2 a}$ in dioxane $(0.5 \mathrm{M}) .{ }^{b}$ Isolated yields after silica gel chromatography. 


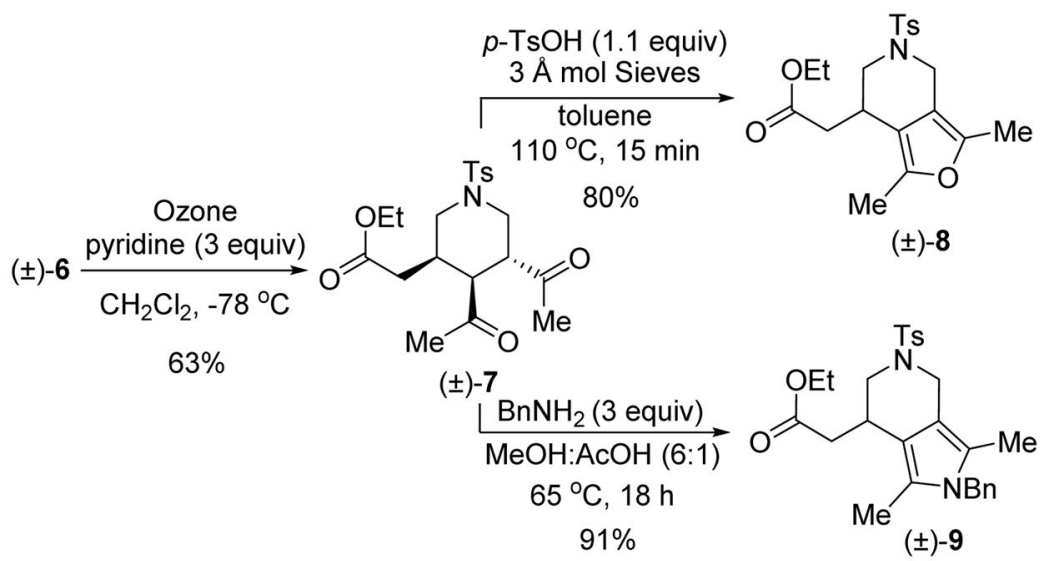

Scheme 4.

Product Diversification 


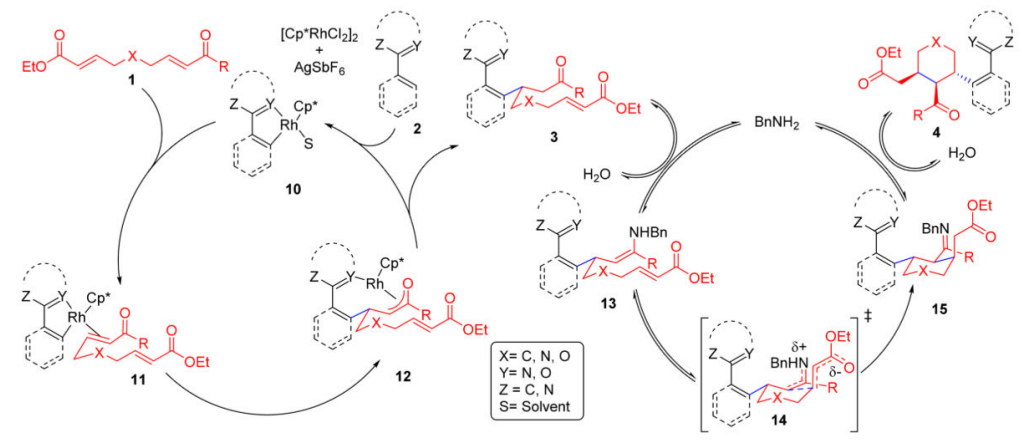

Scheme 5.

Proposed Mechanism for the Transformation 

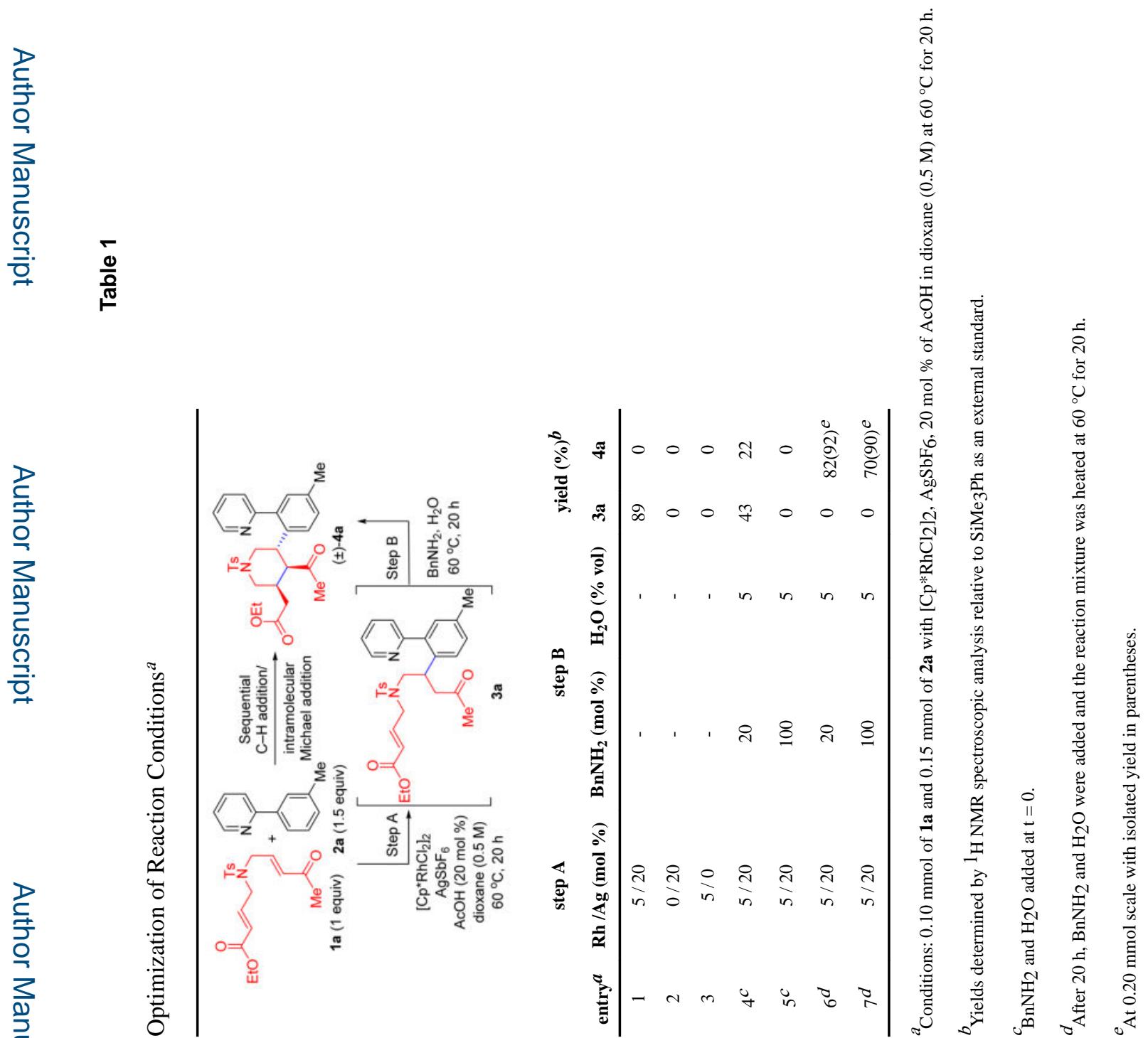